\title{
Groundwater Monitoring at Michael Okpara University of Agriculture Umudike for the Determination of Water Quality
}

\author{
M. U. Igboekwe ${ }^{1}$, A. O. Akankpo ${ }^{1} \&$ R. A. Umenwa ${ }^{1}$ \\ ${ }^{1}$ Department of Physics, Michael Okpara University of Agriculture, Umudike, Abia State, Nigeria \\ Correspondence: M. U. Igboekwe, Department of Physics, Michael Okpara University of Agriculture, Umudike, \\ Abia State, Nigeria. E-mail: igboekwemu@yahoo.com
}

Received: February 27, 2012 Accepted: March 14, 2012 Online Published: June 21, 2012

doi:10.5539/eer.v2n2p21 URL: http://dx.doi.org/10.5539/eer.v2n2p21

\begin{abstract}
Groundwater monitoring of Michael Okpara University of Agriculture Umudike in Abia State, Southeastern Nigeria is presented in this paper with the aim of determining the physical and chemical characteristics of borehole water in the place, and comparing its quality with that of the World Health Organization (WHO). The local geology of the study area, Benin Formation, is of Cretaceous to Recent age. The area is located between latitude $5^{\circ} 28^{\prime}$ and $5^{\circ} 30^{\prime} \mathrm{N}$, and longitude $7^{\circ} 31^{\prime}$ and $7^{\circ} 33^{\prime}$ E. Eight boreholes were sampled and analyzed using the standard laboratory techniques. The $\mathrm{pH}$ value, conductivity, turbidity, total dissolved solids (TDS), acidity and alkalinity of the boreholes were obtained. Turbidity ranged from 86.80 to $92.60 \mathrm{NTU}$. The results showed that the groundwater in the area was acidic with an average $\mathrm{pH}$ value of 5.53, which falls below the World Health Organization (WHO) standard for drinking water (of range 6.50-8.50). The borehole water also has low to moderate conductivities $(100.00$ to $600.00 \mathrm{mg} / \mathrm{L})$. There is need for periodic treatment and monitoring of groundwater in the area.
\end{abstract}

Keywords: groundwater, TDS, borehole, water quality, Umudike

\section{Introduction}

One of the prerequisites of everyday activity and any sustainable development programme is the presence of adequate supply of quality water for human consumption. Groundwater constitutes over $90 \%$ of the world's readily available freshwater resources with remaining $10 \%$ in lakes, reservoirs, rivers and wetlands (Baswinkel, 2000; Asonye et al., 2007). Freshwater quality and availability remains one of the most critical environmental and sustainable issues of the $21^{\text {st }}$ century (UNEP, 2002).

Water is a landscape element and a chemically active mobile substance; it is always on continuous move through the surface and subsurface. Frequent handling of polluting substances on the ground surface involve interventions with water quality, in view of the fact that water is an excellent solvent, chemically active and always on the move according to the laws controlling the hydrodynamics of the water cycle. Once caught by the moving groundwater, pollutants therefore tend to move along with the groundwater, unless chemical reactions along the ground pathways influence the mobility of the pollutant (Akankpo \& Igboekwe, 2011).

Poor management of solid waste materials has resulted to a lot of disastrous effects such as aesthetics, environmental hazards and pollution. Groundwater pollution may also occur due to the contamination potential of leachate from waste (Makey, 1982). Various methods by which solid waste can be disposed are open dumps, sanitary landfill, incineration, on-site disposal, swine feeding and compositing.

Meteorological events and pollution are a few of the external factors, which affect physico-chemical parameters such as $\mathrm{pH}$ and turbidity of the water. They have a major influence on biochemical reactions that occur within the water. Sudden changes of these parameters may be indicative of changing conditions in the water. Internal factors, on the other hand, include events which occur between and within bacterial and plankton population in the water body (Nwankwo \& Igboekwe, 2011; Zamxaka et al., 2004).

Surface or groundwater is never really chemically pure as water invariably dissolves some of the minerals it comes in contact with, at any given time (Etu-efeotor, 1998). These dissolved minerals are contained in the groundwater which influences its hydrogeochemistry and ultimate quality. This study is aimed at determining 
how the dissolved minerals affect the quality of the analyzed water samples in Michael Okpara University of Agriculture, Umudike, Southeastern Nigeria.

Eight water borehole samples located in Michael Okpara University of Agriculture, Umudike, were assessed for quality checks by physico-chemical analysis of the samples in the laboratory. The values of the physicochemical parameters like $\mathrm{pH}$, conductivity, turbidity, acidity, alkalinity and total dissolved solids (TDS) were correlated with the World Health Organization (WHO) values (WHO, 2007).

\section{Location, Geology and Hydrogeology of the Study Area}

Michael Okpara University of Agriculture Umudike is situated within Ikwuano Local Government Area, Abia State, Southeastern Nigeria. The University is located between latitude $5^{\circ} 28^{\prime}$ and $5^{\circ} 30^{\prime} \mathrm{N}$ and between longitude $7^{\circ} 31^{\prime}$ and $7^{\circ} 33^{\prime} \mathrm{E}$, and has an elevation range of 60 to $180 \mathrm{~m}$ above mean sea level (Figure 1).

The geology of the area falls within the Deltaic marine sediments of Cretaceous to Recent age. There are two principal geological formations in the area namely: Ameki Formation and the Coastal Plain Sands, otherwise known as the Benin Formation (Igboekwe et al., 2008). The predominant, however, is the Benin Formation, whose sediments were deposited during the late Tertiary-Early Quaternary period. The formation overlies the Ameki Formation uncomformably and dips southwestwards. The formation is shallow and has an expected thickness of about $200 \mathrm{~m}$. The lithology consists of unconsolidated loosely fine-medium-coarse grained crossbedded sands occasionally pebbly with localized clays and shale.

The two principal geological formations have reliable groundwater that can sustain regional borehole production. However, the Bende-Ameki Formation has little groundwater when compared to the Benin Formation. The high permeability of the Benin Formation, the overlying lateritic earth, and the weathered top of this formation as well as the underlying clay-shale member of the Bende-Ameki series provide the hydrologic conditions favoring aquifer formation in the area.

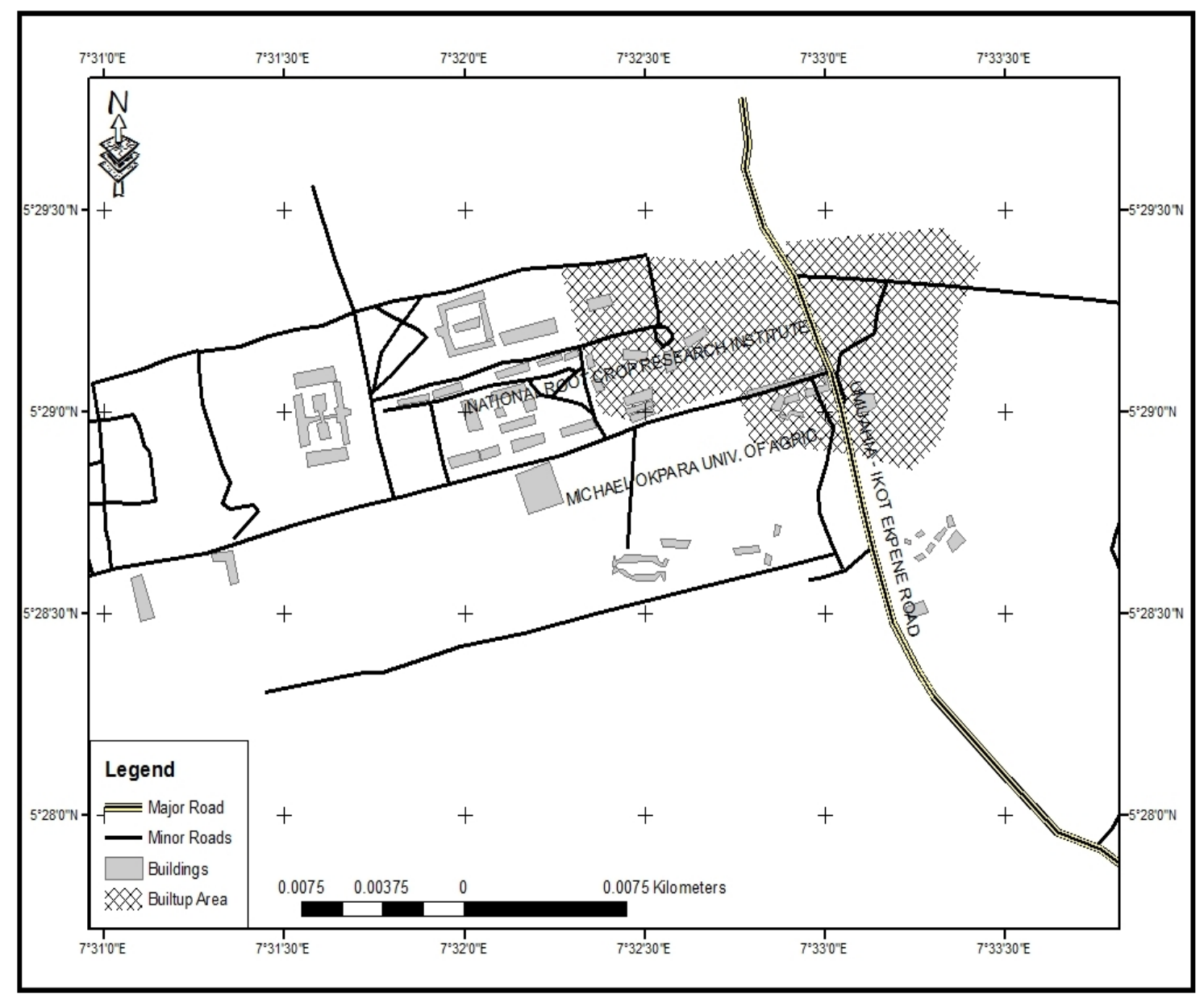

Figure 1. Map of the study area 


\section{Methodology and Data Acquisition}

Groundwater samples were carefully collected from eight existing boreholes in the study area. A Geographic Positioning System (GPS) in which consecutive readings are automatically displayed was used to locate the coordinates and the altitudes of the boreholes (Table 1). The samples were stored in a sterilized $250 \mathrm{ml}$ bottles and transferred to the laboratory for analyses. The conductivity and total suspended solids were determined using a $\mathrm{HACH} 44600-00$ Conductivity/TDS meter at a temperature of $20^{\circ} \mathrm{C}$. The $\mathrm{pH}$ was determined using a $\mathrm{HACH}$ Sension-3 pH meter. The turbidity was determined using a spectrophotometer. The results are tabulated as shown in Table 2.

Table 1. Location of boreholes

\begin{tabular}{cllll}
\hline Borehole no & Borehole location & Latitude $\left.^{(\mathbf{0}}\right)$ & Longitude $^{(\mathbf{0})}$ & Altitude $(\mathbf{m})$ \\
\hline 1 & Poultry block & $5^{\circ} 28.679^{\prime} \mathrm{N}$ & $7^{\circ} 32.256^{\prime} \mathrm{E}$ & 122.20 \\
2 & Admin block & $5^{\circ} 28.726^{\prime} \mathrm{N}$ & $7^{\circ} 32.608^{\prime} \mathrm{E}$ & 131.40 \\
3 & Male hostel & $5^{\circ} 28.848^{\prime} \mathrm{N}$ & $7^{\circ} 32.525^{\prime} \mathrm{E}$ & 126.80 \\
4 & Female hostel & $5^{\circ} 28.903^{\prime} \mathrm{N}$ & $7^{\circ} 32.532^{\prime} \mathrm{E}$ & 129.50 \\
5 & Guest house & $5^{\circ} 29.049^{\prime} \mathrm{N}$ & $7^{\circ} 32.756^{\prime} \mathrm{E}$ & 138.40 \\
6 & VC's lodge & $5^{\circ} 29.176^{\prime} \mathrm{N}$ & $7^{\circ} 32.803^{\prime} \mathrm{E}$ & 144.70 \\
7 & University staff school & $5^{\circ} 29.128^{\prime} \mathrm{N}$ & $7^{\circ} 32.765^{\prime} \mathrm{E}$ & 140.20 \\
8 & Post graduate hostel & $5^{\circ} 28.658^{\prime} \mathrm{N}$ & $7^{\circ} 32.540^{\prime} \mathrm{E}$ & 130.50 \\
\hline
\end{tabular}

Table 2. Some physical and chemical properties of the boreholes

\begin{tabular}{llllllll}
\hline No & Location & $\mathbf{p H}$ & $\begin{array}{l}\text { Conductivity } \\
(\boldsymbol{\mu s} / \mathbf{c m})\end{array}$ & $\begin{array}{l}\text { Turbidity } \\
(\mathbf{N T U})\end{array}$ & $\begin{array}{l}\text { Total dissolved } \\
\text { Solids }(\mathbf{m g} / \mathbf{l})\end{array}$ & $\begin{array}{l}\text { Acidity } \\
(\mathbf{m g} / \mathbf{l})\end{array}$ & $\begin{array}{l}\text { Alkalinity } \\
(\mathbf{m g} / \mathbf{l})\end{array}$ \\
\hline 1 & $\begin{array}{l}\text { Poultry } \\
\text { block }\end{array}$ & 5.20 & 500.00 & 87.60 & 500.00 & 1.01 & 23.40 \\
2 & $\begin{array}{l}\text { Admin } \\
\text { block }\end{array}$ & 5.27 & 400.00 & 92.60 & 600.00 & 1.12 & 15.60 \\
3 & $\begin{array}{l}\text { Male } \\
\text { hostel }\end{array}$ & 4.81 & 400.00 & 89.60 & 600.00 & 2.00 & 20.30 \\
4 & $\begin{array}{l}\text { Female } \\
\text { hostel }\end{array}$ & 4.92 & 450.00 & 90.60 & 800.00 & 1.82 & 21.20 \\
5 & $\begin{array}{l}\text { Guest } \\
\text { house }\end{array}$ & 6.10 & 250.00 & 89.50 & 400.00 & 1.52 & 36.00 \\
6 & $\begin{array}{l}\text { VC's lodge } \\
7\end{array}$ & 6.94 & 600.00 & 88.50 & 900.00 & 0.74 & 18.90 \\
8 & $\begin{array}{l}\text { Univ. staff } \\
\text { school }\end{array}$ & 6.27 & 300.00 & 86.10 & 450.00 & 0.91 & 21.40 \\
\hline & $\begin{array}{l}\text { Post graduate } \\
\text { hostel }\end{array}$ & 4.71 & 100.00 & 91.80 & 150.00 & 1.61 & 21.50 \\
\hline
\end{tabular}




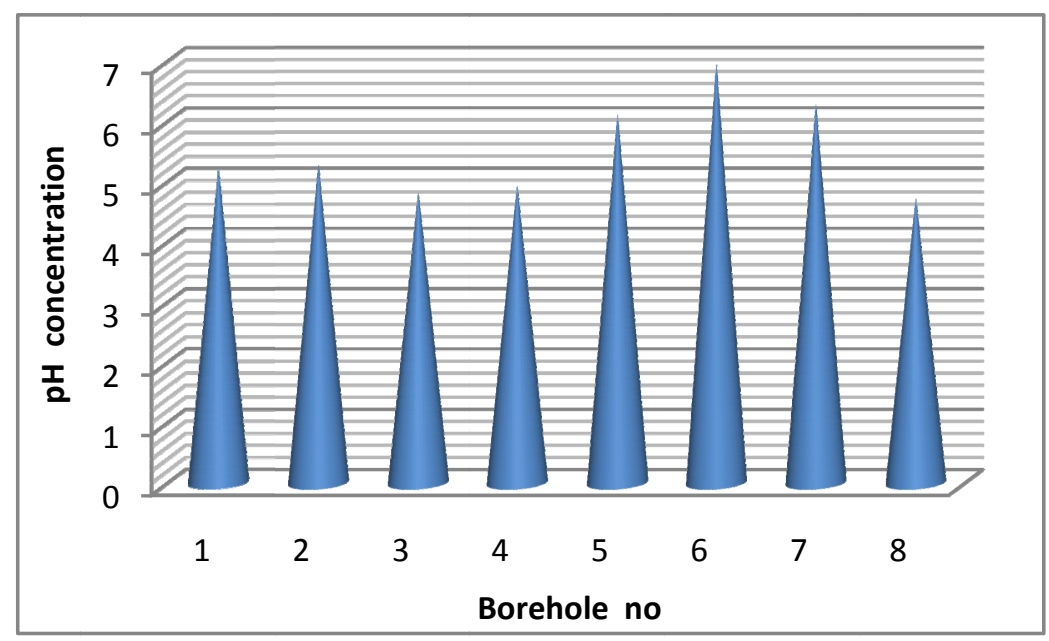

Figure 2. A 3-dimensional cone showing $\mathrm{pH}$ concentration

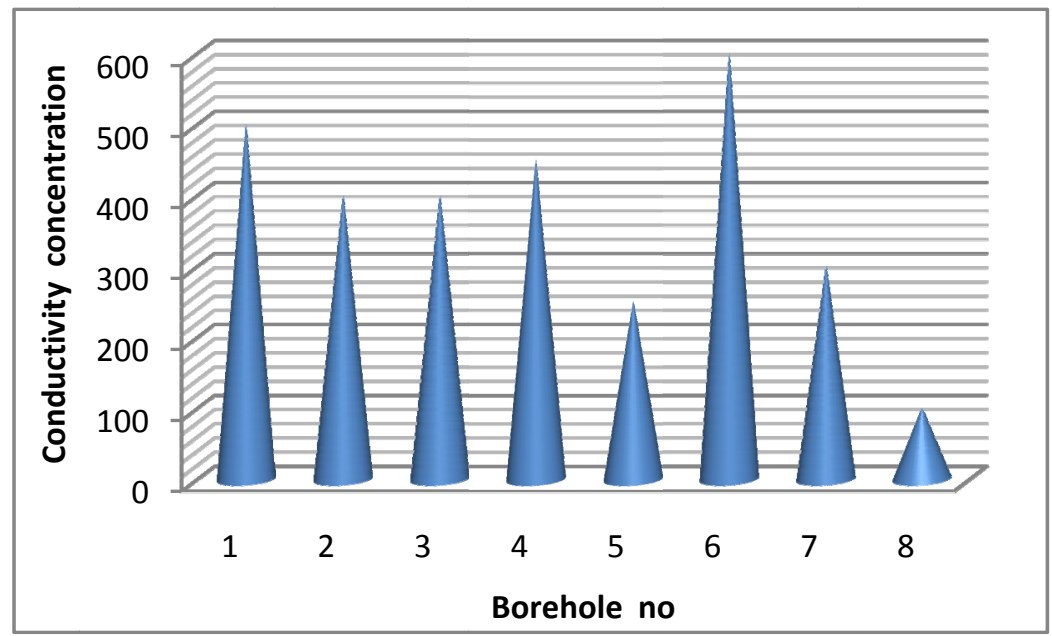

Figure 3. A 3-dimensional cone showing conductivity concentration

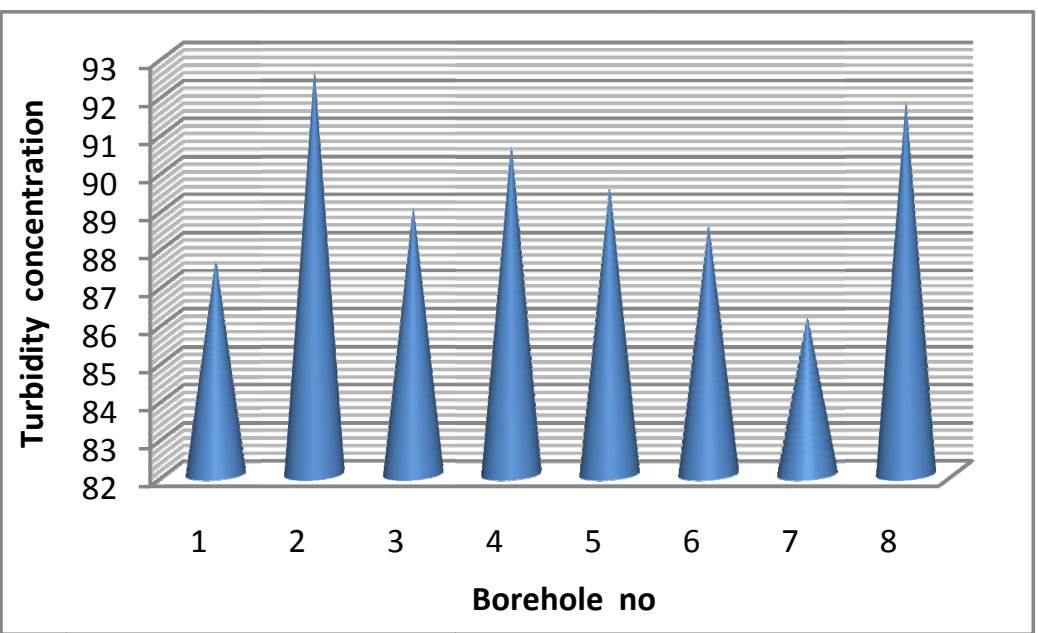

Figure 4. A 3-dimensional cone showing turbidity concentration 


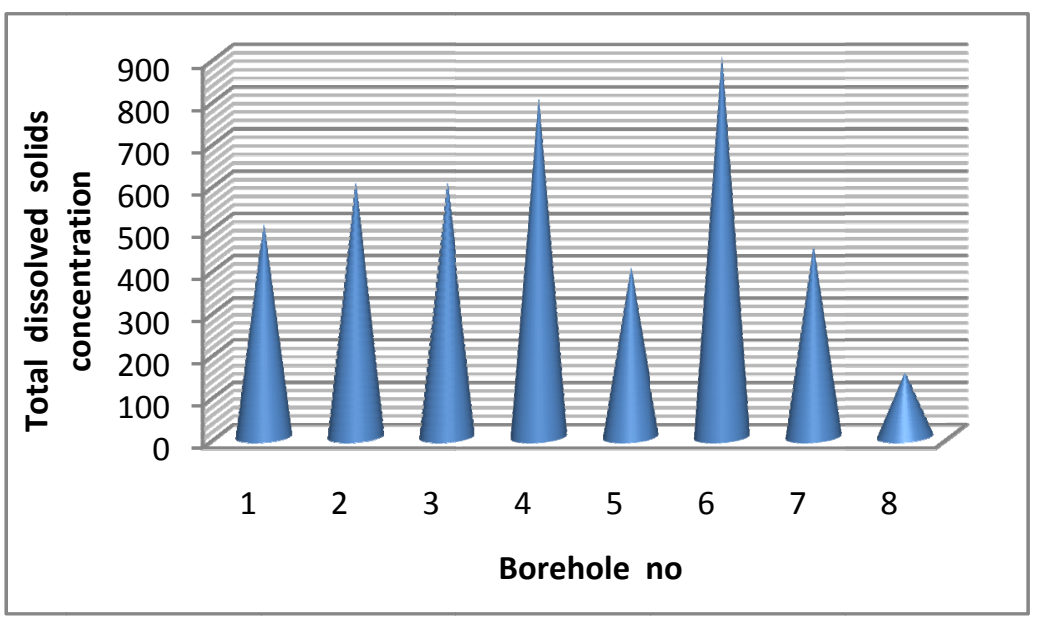

Figure 5. A 3-dimensional cone showing total dissolved solids concentration

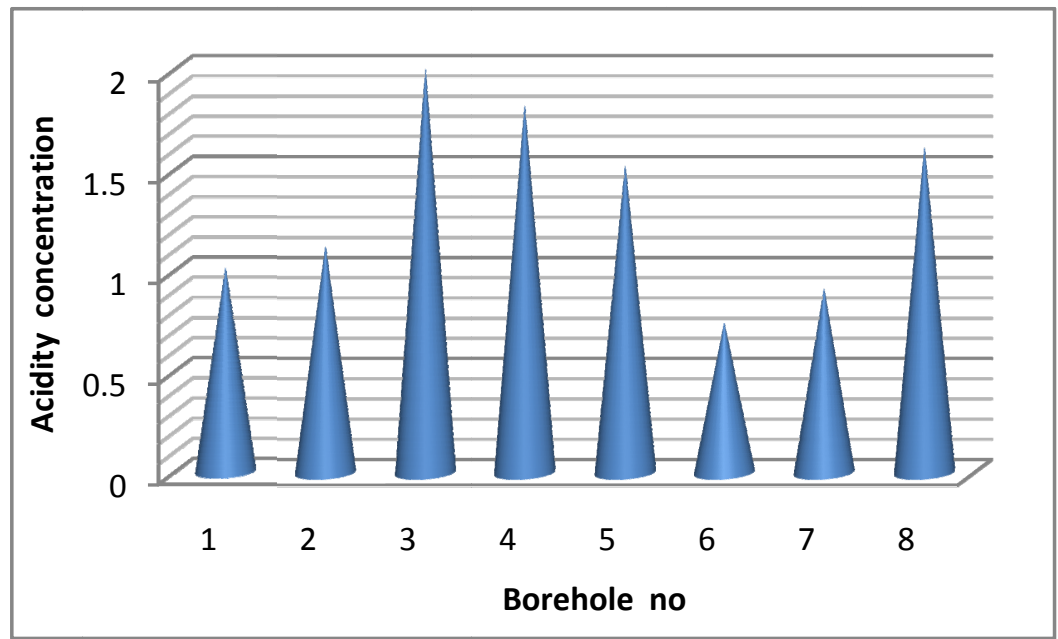

Figure 6. A 3-dimensional cone showing acidity concentration

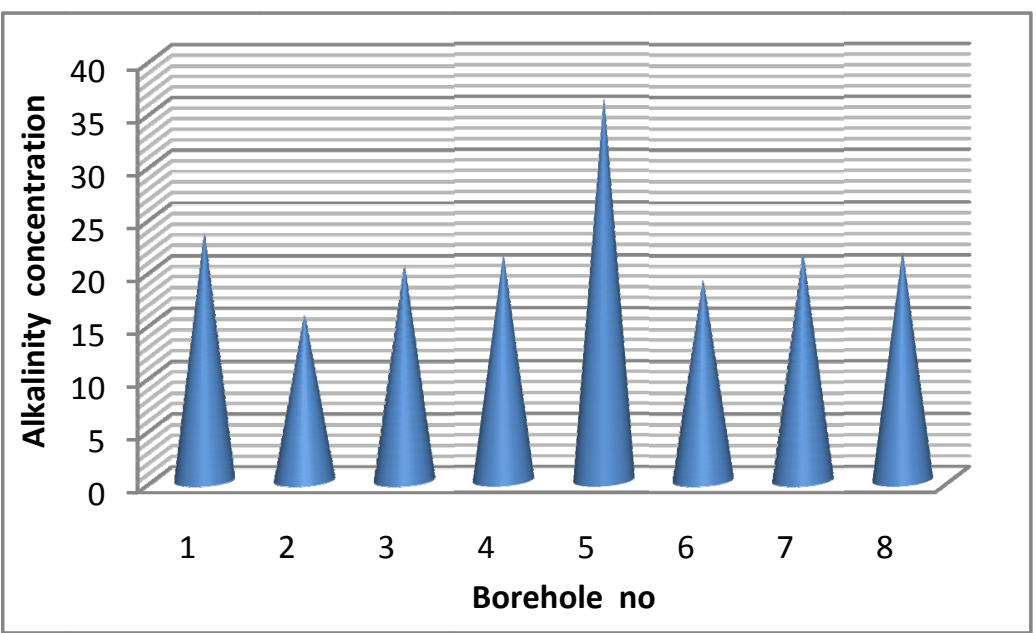

Figure 7. A 3-dimensional cone showing alkalinity concentration 


\section{Results and Discussion}

Table 1 shows the borehole no, coordinates (latitudes and longitudes) and elevations of the eight boreholes used for this study. From Table 1, it can be seen that borehole no.1 is situated at the lowest altitude of the study area, while borehole no. 6 is situated at the highest point of the study area. Table 2 shows the results of the laboratory analyses of the pollution indicators. Borehole no. 6 has the highest $\mathrm{pH}$ value of 6.94 , while borehole no. 8 has the lowest $\mathrm{pH}$ value of 4.71 , followed closely by borehole no. 3 (Figure 2). The results showed that the groundwater in the area was acidic with an average $\mathrm{pH}$ value of 5.53, which falls below the World Health Organization (WHO) standard for drinking water (of range 6.50-8.50). Therefore, borehole no. 6 appears to be the only one that falls within the WHO standard.

According to Zamxaka et al. (2004), $\mathrm{pH}$ values ranging from 3.00 to 10.00 could favour both indicator and pathogenic micro-organism growth. Physical parameters such as $\mathrm{pH}$ and temperature have a major influence on bacteria population growth. The low $\mathrm{pH}$ values of the boreholes water may also be due to the agricultural activities in the area. These solutions diffuse through the sandy permeable layers of the formation to form weakly acidic solutions which are washed down into the aquifer containing the groundwater. The highest value of conductivity $(600.00 \mu \mathrm{s} / \mathrm{cm})$ was recorded at borehole no. 6 , while the lowest value of conductivity $(100.00$ $\mu \mathrm{s} / \mathrm{cm}$ ) was recorded at borehole no. 8 (Figure 3). Conductivity of the water can be related to the total dissolved solids concentration, but the relationship may not be a constant (White, 2005).

Borehole no. 2 has the highest turbidity value of $92.60 \mathrm{NTU}$, while borehole no.7 has the lowest turbidity value of 86.10 NTU (Figure 4). The turbidity values recorded for all the samples were above the WHO acceptable limit of 5.00 NTU. High turbidity values correspond to rainy season (Zamxaka et al., 2004). Turbidity is always typically high during a heavy rain and a storm as a consequence of rapid erosion of surface soils into rivers and groundwater. Water turbidity varies from $1.00 \mathrm{NTU}$ in clear springs or deep groundwater, to $160 \pm 60 \mathrm{NTU}$ in mud-laden surface waters (DWAF, 1998). Borehole no.6 has the highest TDS value of $900.00 \mathrm{mg} / \mathrm{l}$, while borehole no. 8 has the lowest TDS value of $150 \mathrm{mg} / 1$ (Figure 5). Dissolved solids comprise of inorganic salts and some small amounts of organic that are dissolved in water. TDS test provides a qualitative measure of the amount of dissolved ions in water, and can be used as an indicator test to determine the general quality of water.

Borehole no. 3 has the highest acidity value of $2.00 \mathrm{mg} / \mathrm{l}$, while borehole no. 6 has the lowest acidity value of $0.74 \mathrm{mg} / \mathrm{l}$ (Figure 6). The acidity of the area may have resulted from landfill gases arising from the decomposition of waste materials from agricultural activities into the subsurface. According to Nwankwo and Igboekwe (2011), the low pH (high acidity values) could also be as a result of the amount of dissolved carbondioxides and biocarbonates present in the aquiferous rocks. The $\mathrm{pH}$ values of the groundwater samples fall within the $\mathrm{pH}$ values of the soil, which ranges from 4.50 to 5.70 (Nuga \& Akinmola, 2011). Borehole no. 5 has the highest alkalinity value of $36.00 \mathrm{mg} / \mathrm{l}$, while borehole no. 2 has the lowest alkalinity value of $15.60 \mathrm{mg} / \mathrm{l}$ (Figure 7).

Generally, the water samples are colourless, odourless and tasteless, showing that the geologic formation, viz, Benin Formation upon which these boreholes are sitting present very good aquifer. However, erosion and infiltration processes in the area lead to low $\mathrm{pH}$ (high acidity) and high turbidity values obtained in the study area.

\section{Conclusion}

The foregoing groundwater monitoring studies have been carried out at Michael Okpara University of Agriculture Umudike with the sole aim of determining the water quality within the study area. The local geology of the study area, Benin Formation, is of Cretaceous to Recent age. The locations and topographic elevations of the boreholes have been accurately determined using the appropriate equipment. Some physical and chemical properties of the water samples from these boreholes have equally been determined.

Results obtained show that the water quality parameters of concern were $\mathrm{pH}$ and turbidity because they had marked departure from WHO standard. The groundwater in the area is acidic and of high turbidity values. The results showed that the groundwater in the area was acidic with an average $\mathrm{pH}$ value of 5.53 , which falls below the World Health Organization (WHO) standard for drinking water (of range 6.50-8.50). Therefore, borehole no. 6 appears to be the only one that falls within the WHO standard. Groundwater monitoring and prior geophysical study have therefore proved to be very suitable ways of determining groundwater quality of Michael Okpara University of Agriculture, Umudike. 


\section{References}

Akankpo, A. O., \& Igboekwe, M. U. (2011). Monitoring groundwater contamination using surface electrical resistivity and geochemical methods. Journal of Water Resource and Protection, 3(5), 318-324. http://dx.doi.org/10.4236/jwarp.2011.35040

Asonye, C. C., Okolie, N. P., Okenwa, E. E., \& Iwuanyawu, U. G. (2007). Some Physio-chemical characteristics and heavy metal profiles of Nigerian rivers, streams and wetlands. Afr. J. Biotechnol., 6(5), 617-624.

Baswinkel, J. A. (2000). Information note. International Groundwater Resources Assessment Center (IGRAC), Netherlands Institute of Applied Geosciences, Netherlands.

Department of Water Affairs and Forestry (DWAF). (1998). Quality of domestic water supplies-Vol. 1 Assessment Guide. Department of Water Affairs and Forestry, Pretoria.

Etu-Efeotor, J. O. (1998). Hydrochemical analysis of surface and groundwater of Gwagwalada Area of Central Nigeria. Global Journal of Pure and Applied Sciences, 4(2), 153-162.

Igboekwe, M. U., Gurunadha Rao,V. V. S., \& Okwueze, E. E. (2008). Groundwater flow modelling of Kwa Ibo River Watershed, Southeastern Nigeria. Hydrological Processes, 22(10), 1523-1531. http://dx.doi.org/10.1002/hyp.6530

Makey, K. S. (1982). Natural buffers for sludge leachate stabilization. Groundwater, 20(4), $420-429$. http://dx.doi.org/10.1111/j.1745-6584.1982.tb02762.x

Nuga, B. O., \& Akinmola, G. E. (2010). Soil survey information for sustainable agriculture in Ikwuanu Local Government area, Abia State, South East Nigeria. Second RUFORUM Biennial Meeting, 20-24 ${ }^{\text {th }}$ September, Entebbe, Uganda, pp. 555-557.

Nwankwo, C. N., \& Igboekwe, M. U. (2011). The mineral effects of sedimentary layers on groundwater in Choba, Rivers State, Nigeria. The IUP Journal of Environmental Sciences, 5(2), 20-27.

UNEP (United Nations Environmental Program). (2002). Global Environmental Outlook (GEO-3), p. 43.

White, R. E. (2005). Spatial variability of shallow groundwater levels, electrical conductivity and nitrate concentration and risk assessment of nitrate contamination in North China Plain. Environmental International Journal, 31(16), 896-903.

World Health Organization (WHO). (2007). International Drinking Water Standards (3rd ed.). WHO, Geneva.

Zamxaka, M., Pironcheva, G., \& Muyima, N. (2004). Microbiological and physico-chemical assessment of the quality of domestic water sources in selected rural communities of the Eastern Cape Province, South Africa. Water SA, 30(30), 333-339. 